\title{
PENGARUH PERMAINAN ULAR TANGGA KATA BESAR MODIFIKASI TERHADAP KEMAMPUAN MEMBACA ANAK DI TAMAN KANAK-KANAK ISLAM KHAIRA UMMA PADANG
}

\author{
Sri Nanda Amelia Putri ${ }^{1}$ Izzati $^{2}$, Indra Yeni ${ }^{3}$ \\ Universitas Negeri Padang \\ Email: Srinanda1306@gmail.com
}

\begin{abstract}
ABSTRAK
Tujuan dari penelitian ini adalah untuk mengetahui pengaruh permainan ular tangga kata besar modifikasi terhadap kemampuan membaca anak. Penelitian ini menggunakan metode kuantitatif dengan bentuk pendekatan quasy eksperimen. Dari penelitian yang telah dilakukan didapatkan hasil pada kelas eksperimen yang menggunakan permainan ular tangga kata besar modifikasi mendapatkan rata-rata nilai yang tinggi dimana dapat dibandingkan dengan nilai yang didapati oleh anakanak yang berada di kelas kontrol yang menggunakan media papan tulis. Rata-rata kelompok eksperimen adalah 79,16 dan kelompok kontrol dengan rata-rata 70,31. Dari hasil analisis data yang sudah dilakukan bahwa $t_{\text {hitung }}>t_{\text {tabel, }}$ yaitu $(2,93046>$ 2,07387). Maka dari itu dapat ditarik kesimpulan bahwa permainan ular tangga kata besar modifikasi berpengaruh terhadap kemampuan membaca anak di Taman Kanak-kanak Islam Khaira Ummah Padang.
\end{abstract}

Kata Kunci : ular tangga kata besar modifikasi, kemampuan membaca anak

\begin{abstract}
The purpose of this study was to find out the effect of the snake ladder game on the big word modification of children's reading ability. This study uses a quantitative method in the form of a quasy experimental approach. From the research that has been done, the results obtained in the experimental class that uses the game snake ladders, modified words get a high average value which can be compared with the value found by children in the control class using whiteboard media. The average experimental group was 79.16 and the control group with an average of 70.31. From analysis data it take the result that bhas been done that $t$ count> $t$ table, that is (2.93046> 2.07387). Therefore, it can be concluded that the game of big word modified snakes and ladders influences the ability to read children in Khaira Ummah Padang Islamic Kindergarten. Keywords: big snake ladder word modification game, children's reading ability
\end{abstract}



PEDAGOGI: Jurnal Anak Usia Dini dan Pendidikan Anak Usia Dini

Volume 5 Nomor 2 Agustus 2019

6P-ISSN: 2599-0438; E-ISSN: 2599-042X

\section{PENDAHULUAN}

Masa usia dini merupakan masa-masa yang sangat penting bagi perkembangan dan pertumbuhan dan merupakan masa keemasan bagi anak. Di sebut masa keemasan karena pada masa ini anak akan sangat peka terhdap lingkungannya, oleh karena itu anak perlu di berikan stimulasi-stimulasi yang dapat membentuk dan mengoptimalkan potensi yang ada pada diri anak. Fadillah (2012) menyatakan bahwa anak usia dini merupakan anak yg berusia 0-6 tahun, pada masa ini merupakan masa yang paling tepat untuk menanmkan nilai-nilai kebaikan dalam membentuk karakter dan kepribadian anak. Salah satu upaya yang dapat di lakukan untuk merealisaikan hal tersebut adalah dengan memberikan pelayanan pendidikan kepada anak. Berdasarkan permendikbud nomor 146 tahun 2013, Pendidikan anak usia dini merupakan suatu upaya pembinaan yang di tujukan kepada anak sejak lahir sampai usia enam tahun yang dilakuakan melalui pemberian rangsangan pendidikan unrtuk membantu pertumbuhan dan perkembangan jasmani dan rohani agar anak memiliki persiapan dalam memasuki pendidikan lebih lanjut. Pendidikan anak usia dini memiliki peranan penting bagi pengembangan potensi serta membentuk karakter dapat menyesuaikan diri dengan lingkungan dan menciptakan individu yang berguna bagi masyarakat.

Taman Kanak-kanak merupakan sebuah lembaga pendidikan prasekolah yang berada pada jalur pendidikan formal. Taman Kanak-kanak bertujuan untuk memberikan stimulasi untuk membantu pertumbuhan dan perkembangan segala aspek perkembangan anak, agar anak memiliki kesiapan dalam memasuki pendidikan lebih lanjut. Taman Kanak-kanak adalah salah satu penyelenggaraan Pendidikan Anak Usia Dini yang implementasinya lebih menekankan pada prinsip bermain sambil belajar, belajar seraya bermain. Dalam pelaksanaaan pendidikan anak usia dini penyelenggara pendidikan akan menyajikan pembelajaran yang dapat mengambangakan berbagai bidang pengembangan salah satunya adalah perkembangan bahasa. 
Kemendiknas (2010: 7) menyatakan bahwa Bahasa dikembangkan sebagai cara untuk mengungkapkan pikiran yang sederhana secara tepat, mampu berkomunikasi secara efektif dan membangkitkan minat untuk dapat berbahasa Indonesia yang baik dan benar. Kemudian dalam hasil belajar diharapkan agar anak dapat menunjukan kata sesuai gambar, menyebutkan kata dengan membaca tulisan, dan menyebutkan simbol dalam kata. Perkembangan bahasa anak usia dini pada dasarnya masih belum berkembang secara optimal. Untuk mengembangkan kemampuan bahasa anak perlu diberikan rangsangan melalui komunikasi yang aktif dengan menggunakan bahasa yang baik dan benar.

Kemampuan membaca merupakan salah satu bentuk dari perkembangan bahasa anak. Dimana membaca merupakan kesatuan kegiatan yang terpadu yang mencakup beberapa kegiatan seperti mengenali huruf dan kata-kata, menghubungkan dengan bunyi serta maknanya, serta menarik kesimpulan mengenai maksud bacaan. Oleh sebab itu kemampuan membaca anak perlu dirangsang dan dikembangkan sejak dini. Kemampuan membaca sangat penting bagi perkembangan bahasa anak dan sebagai bekal kesiapan dalam memasuki jenjang pendidikan anak selanjutnya maka kemampuan guru di Taman Kanakkanak dituntut untuk lebih kreatif dalam mengajarkan membaca kepada anak.

Aulia (2012:40) menyatakan bahwa kemampuan membaca yang akan dikembangkan seperti: 1) kemampuan auditorial, yakni kemampuan dalam memahami suarasuara baik konsonan dan vocal; 2) kemampuan diskriminasi visual yakni anak dapat membedakan berbagai macam huruf yang ada; 3) kemampuan membuat hubungan suara dan symbol yang menandainya; 4) kemampuan anak dalam berbahasa lisan 5) kemampuan anak dalam mengenali kata; 6) kemampuan anak menggunakan bahasa tutur. Dari hasil observasi awal dan penilaian peneliti di Taman Kanak-kanak Islam Khaira Ummah Padang terlihat bahwa kemampuan membaca anak kurang berkembang secara optimal, hal ini terlihat dari masih adanya anak-anak belum 
sepenuhnya mampu mengenal simbol-simbol huruf dan membedakannya, masih ada anak yang sulit membaca kata pada gambar, anak kurang mampu merangkai huruf menjadi kata, kurang mampunya anak menghubungkan gambar/benda dengan kata dan anak kurang mampu menghubungkan dan menyebutkan tulisan sederhana dengan simbol yang melambangkannya.

Berdasarkan uraian di atas, peneliti mencermati bahwa fenomena tersebut perlu diminimalisir dengan cara melakukan penelitian melalui sebuah media yang menarik yaitu ular tangga raksasa modifikasi. Menurut Kurniasih (2014: 123 )Permainan ular tangga adalah salah satu jenis permainan tradisional yang mendunia. Permainan ini merupakan jenis permainan kelompok, melibatkan beberapa orang dan tidak dapat digunakan secara individu Papan permainan dibagi dalam kotak-kotak kecil dan di beberapa kotak digambar sejumlah "tangga" atau "ular" yang menghubungkannya dengan kotak lain.

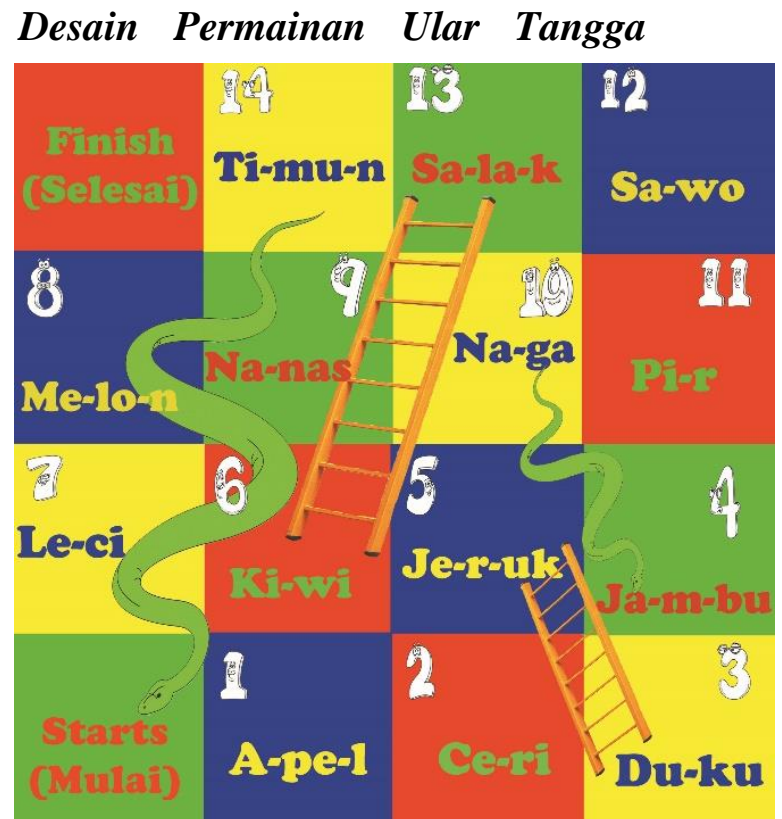

Kurniawati (2014: 2) menyatakan bahwa alasan digunakan permainan ular tangga terhadap kemampuan membaca anak adalah bertujuan untuk memperjelas konsep membaca dengan lebih menyenangkan, mampu memuaskan rasa ingin tahu, membayangkan dan menerjemahkan perngalaman bermain tersebut menjadi sesuatu yang bermakna bagi anak. Penggunaan permainan ular tangga modifikasi ini diharapkan dapat mempermudah guru dalam proses pengenalan kata pada anak. Sehubungan dengan itu peneliti tertarik untuk melakukan penelitian dengan judul : "Pengaruh permainan ular tangga kata besar modifikasi terhadap kemampuan membaca anak di Taman Kanak-kanak Islam Khaira Ummah Ikur Koto Padang”. 


\section{METODE PENELITIAN}

Jenis penelitian ini adalah penelitian kuantitatif dengan metode eksperimen. Kemudian metode ekperimen ini di bagi menjadi macam macam jenisnya maka penelitian ini di kategorikan sebagai penelitaian Quasi eksperiment. Penelitian dengan metode quasi eksperimen atau eksperimen semu menggunakan kelas control untuk mengontrol variable-variabel luar yang dapat mempengaruhi hasil penelitian Sugiono, 2016). Penelitian ini bertujuan mengetahui sejauh mana Pengaruh Permaianan Ular Tangga Raksasa Modifikasi Terhadap Kemampuan Membaca Anak di Taman Kanak-kanak Islam Khaira Ummah Ikur Koto Padang dengan membandingkan hasil belajar kelas eksperimen dan kelas control.

Populasi dalam penelitian ini adalah Taman Kanak-Kanak Islam Khaira Ummah terletak di Jl. Raya Lubuk Minturun Tabing Ikur Koto Kec. Koto Tangah Padang. Taman Kanak-kanak Islam Khaira Ummah Ikur Koto Padang memiliki jumlah anak sebanyak 105 orang, yang terbagi dalam tujuh kelompok belajar, yaitu kelompok B1, B2 dan
B3, B4, B5, B6, B7. Populasi Taman Kanak-kanak Islam Khaira Ummah Padang. kelas yang akan dijadikan sampel dalam penelitian ini adalah kelas B3 dan B7. Dimana kelompok B7 dijadikan kelompok eksperimen dan kelompok B3 dijadikan kelompok kontrol dengan pertimbangan jumlah anak yang sama, tingkat kemampuan anak yang sama, fasilitas belajar yang sama dan rekomendasi dari guru kedua kelompok serta kepala sekolah.

\section{HASIL}

Data yang dideskripsikan dalam penelitian ini terdiri dari dua kelas yaitu data tentang hasil pre-test (kemampuan awal) kemampuaun membaca pada anak sebelum diberikan treatment terhadap kelas eksperimen dan kelas kontrol. Penelitian ini dilakukan sepuluh kali pertemuan, lima kali pertemuan kelas eksperimen (B2) terdiri dari satu kali pre-test dilanjutkan treatment tiga kali dan dilanjutkan dengan post-test. Kelas kontrol (B4) lima kali pertemuan terdiri dari satu kali pretest dilanjutkan treatment tiga kali dan dilanjutkan dengan post-test. Pada saat melakukan pre-test peneliti menggunakan permainan ular tangga 
kata besar modifikasi pada kelas eksperimen dan menggunakan majalah dan papan tulis pada kelas konrol. Table berikut merupakan hasil perhitungan pre test:

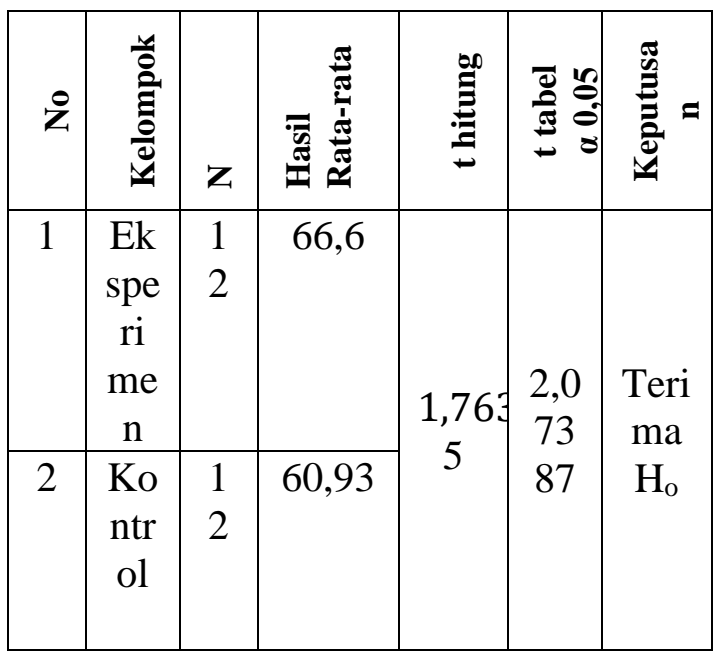

Table diatas menyatakan bahwa hipotesis $\mathrm{Ha}$ ditolak atau $\mathrm{H}_{\mathrm{o}}$ diterima. Simpulan dari data tersebut adalah terdapatnya perbedaann yang terliha antara hasil kemampuaun awall anak kelas eksprimen dan kelas kntrol dalam pengembangan kemampauan membaca. Data dari hasil post-test penelitian kelas eksprimen dan kelas kontrl dilakukann dengan uji hipotesis mengunakan teknik t-tes, bertujuan yang untuk mengetahuii apakabh hasil penelitian Post-test terdapat perbedaan yang signifikan untuk kelas eksperimen dan kelas kontrol. Apabila $t_{\text {hitung }}<t_{\text {tabel }}$ berarti tidak terdapat perbedaan yang signifikan antara kedua kelas. Dengan menggunakan t-test untuk hasil uji hipotesis didapatkan hasil perhitungan pot test sebagai berikut: 


\begin{tabular}{|c|c|c|c|c|c|c|}
\hline$\stackrel{8}{z}$ & 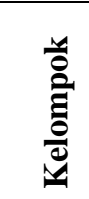 & Z & 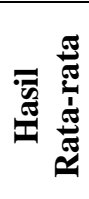 & 萻 & 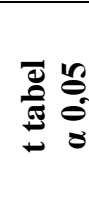 & 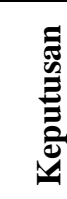 \\
\hline 1 & $\begin{array}{l}\text { Eks } \\
\text { peri } \\
\text { men }\end{array}$ & 12 & $\begin{array}{l}79, \\
16\end{array}$ & $\begin{array}{l}2,9 \\
304\end{array}$ & $\begin{array}{l}2,0 \\
738\end{array}$ & $\begin{array}{l}\text { To } \\
\text { lak }\end{array}$ \\
\hline 2 & $\begin{array}{l}\text { Kon } \\
\text { trol }\end{array}$ & 12 & $\begin{array}{l}70, \\
31\end{array}$ & 6 & 7 & $\mathrm{H}_{\mathrm{o}}$ \\
\hline
\end{tabular}

Berdasarkan table diatas

bisa dikatakan bahwa hipotesa $\mathrm{Ha}$ diterima atau Ho ditolak. Bisa disimpulkan bahwa ada perbedaan yang terlihat antara hasil post test anak dikelas ekperimen (B2) dan kelas kntrol (B4) dalam pengembangan kemampuan membaca. Kemudian dari data tersebut dapat disimpulkan bahwasanya perkembangan kemampuan membaca anak berpengaruh dengan mnggunakan permainan ular tangga kata besar modifikasi dibandingkan dengan media papan tulis dan majalah. Perbandingan hasil penilaian pertama dan terakhir terlihat dari nilai tertinggi dan terendah, nilai rata-rata kelas yang didapatkan anak pada hasil penialaian akhir dimana nilai rata-rata menjadi lebih meningkan daripada rata-rata hasil awal setelah melakukan treatment. Lebih jelasnya

dapat dilihat pada grafik perbandingan pre test dan post test dibawah ini :

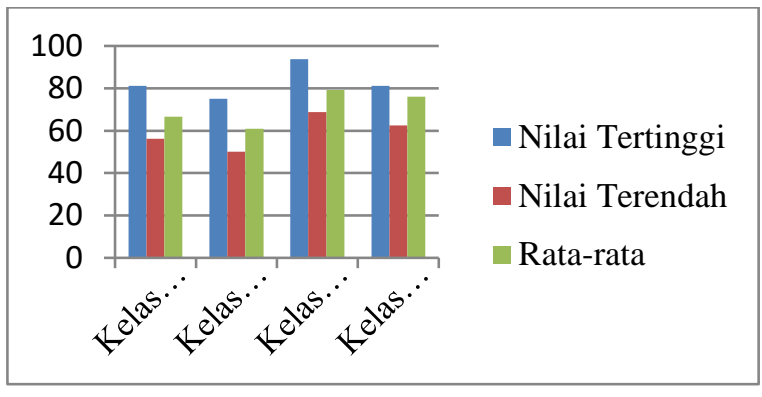

Dari penjelasan diatas, perkembangan kemampua membaca pada anak terlihat pada hasil kelas ekperimen (B2) jauh lebih baik dari pada perkembangan kemampuan membaca anak dikelas kontrl (B4). Hal ini dapat dilihat dari nilai ratarata anak kelompok eksprimen yang lebih tinggi dari anak kelompok kontro. Jadi disimpulakn kegiatan ber main dengan permainan ular tangga kata besar modifikasi mempengaruhi kemampuan membaca anak.

\section{PEMBAHASAN}

Sebelum melakukan penelitian peneliti membuat kisi-kisi instrument sebagai pedoman penilaian kemampuan membaca anak. Kisi-kisi tersebut sudah divalidkan oleh dosen ahli bidang bahasa. Setelah validator menyeetujui kevalidan kisi-kisi, 
peneliti kemudian menguji kisi-kisi tersebut di TK Jannatul Ma'wa Padang. Setelah data didapatkan peneliti mulai menguji validitas tes dan uji reliabilitas guna mengetahui akurat, nyata dan dapat dipertanggung jawabkan atau tidaknya kisi-kisi tersebut, peneliti menggunakan empat item pernyataan yang sudah diuji valid dan reliabelnya dalam menilai kemampuan bahasa yaitu membaca anak di TK islam Khaira Ummah Padang.

Penelitian ini dilakukan didasari dengan teori membaca menurut Yulsyofriend (2013: 60) kemampuan yang berkaitan dengan kesiapan membaca yang akan dikembangkn pada anak yaitu: kmampuan mrangkai dan mellengkapi suku kata, kmampuan mmbedakan bunyi, kampuan membedakan kata dan suku kata, serta anak dpat memahami objek dan pengalaman dngan berbagai mcam gambar. Penelitian ini menerapkan permainan ular tangga dalam pembelajaran agar anak dpat belajar aktif, menyenangkan, sehingga kemmapuan anak dalam membaca dapat berkembang. Sejalan dengan
Yufita (2015) permainan ular tangga kata cukup efektif untuk mengembangkan kmampuan mengenal kata, karena pada usia lima sampai enam tahun masih pada tahap praoperasional yaitu anak belajar melalui benda konkret.

Sedangkan pada kelompok control yang menggunakan media papan tulis dan majalah, tidak begitu diminati oleh anak sebab anak merasa kegiatan yang di laukan sama dari waktu kewaktu yang membuat anak bosan dan enggan melakukannya terlebih dalam hal belajar. Oleh karenanya banyak anak tidakn memperhatikan guru yang mengajar dan pembelajaran pun menjadi kurang efektif, jadi penggunaan permainan ular tangga kata besar modifikasi berpengaruh terhadap kemampuan membaca anak. Karena dapat terlihat saat anak melakukan kegiatan dimana anak bisa membaca kata yang ada, membaca suku kata, mengelompokkan kata dengan bunyi awal yang sama, serta menghubungkan kata dengan gambar. 
Saat turun kelapangan, membaca aakan kelas eksprimen, penelitian ini diawali denganb peneliti melaksankan pre test untuk melihat kemampuan awal anak, dimana peneliti melakukan kegiatan bermain dengan menggunakan permainan ular tangga kata besar dengan subtema kereta api dan kegiatan membaca majalah dan papan tulis dikelas control. Pada saat pretest, peneliti melihat banyak anak yang antusia ketika belajar membaca dengan menggunakan permainan ular tangga kata besar.

Pada saat meneliti terlihatlah perbedaan dari kelas eksprimen dengan kelas kntrol Dikarenakan kegiatan bermain dengan menggunaka permainan ular tangga kata besar modifikasi merupakan permainan dengan cara yang baru bagi anak dan belom pernah dipelajari sebelumnya. Sedangkan pada kelas control anak melaksanakan kegiatan membaca dengan menggunakan majalah dan papan tulis, terlihat anak kurang memberi respon dalam melaksanakan kegiatan ini sehingga kegiatan menjadi tidak menarik bagi anak. Dengan demikian hasil perkembangan kemampuan lebih baik dibandnhkan anak kelas kontrl. Maka disimpulkan terdapat pengaruh yang signifika dalam kegiatan membaca dengan permainan ular tangga kata besar modifikasi terhadap kemampyuan membaca anak di TK islam Khaira Ummah Padang.

\section{KESIMPULAN}

Penelitian ini dilaksanakan di TK Islam Khaira Ummah Padang, dimana terdapat perbedaan aantara kelas eksprimen (B2) dengan kelas kntrol (B4). Terbukti bahwa dengan menggunakan ular tangga kata besar modifikasi dapat berpengaruh pads kemampuan membaca anak. Sehingga nilai rataan yang diperoleh dari kelas eksprimen lebih tinggi $(79,16)$ dibandingkan dengna kelompok kntrol dengan rataan nilai (70,31).

Melalui hasil uji hipotesa
diperoleh thitung $>$ tabel dimana
$2,93046>2,07387$ yang dibuktikan
melalui taraf signifikn $\alpha=0,05$ dan
dk=22 berarti hipotesa Ha diterima
dan $\mathrm{H}_{0}$ ditolak, maka disimplkan
bahwa permainan ular tangga kata
besar modifikasi memiliki pengaruh


terhadap kemampuan membaca anak di TK islam Khaira Ummah Padang. penelitian ini bisa di jadikan sebagai rujukan bagi penelitian berikutnya.

\section{SARAN}

Terbukti dengan adanya
permainan ular tangga kata besar
modifikasi berpengaruh terhadap
kemampuan membaca, sehingga
dapat disarankan kepada guru dalam
mengembangkan kemampuan
membaca anak hendaknya guru
merancang kegiatan dan
menggunakan media dan permainan yang menarik dan bervariasi kepada anak, Sehingga nantinya saat pembelajaran anak menjadi antusias dan bersemangat dalam pembelajaran. Kemudian disarankan kepada sekolah agar dalam mengembangkan pembelajaran khususnya kemampuan berhitung hendaknya sekolah dapat memberikan

arahan,motivasi,dorongan serta vasilitas kepada guru untuk menciptakan inovasi-inovasi baru dalam kegiatan pembelajaran untuk mengembangkan kemampuan berhitung anak salah satunya dengan menggunakan permainan ular tangga kata besar modifikasi. Kemudian

\section{DAFTAR RUJUKAN}

Aulia.2012. Revolusi Pembuatan Anak Candu Membaca.Flashbook:Jogjakar ta

Fadlillah, Muhammad. 2012. Desain pembelajaran PAUD.

Yogyakarta: Ar-ruzz

Media

Kemendiknas. 2010. Pengembangan Pendidikan Budaya dan Karakter Bangsa. Jakarta: Kementrian Pendidikan Nasional

Kurniasih, Ria. 2014. Media Ular Tangga Jejak Petualang Sebagai Media

Pembelajaran Untuk Anak Usia Dini. Jurnal Pascasarjana UPI Vol. 5 No. 2 ,

November 2014

Kurniawati, Rindha. 2014. Meningkatkan Kemampuan Berhitung dengan Permainan Ular Tangga Pada Anak Kelompok B TK Yunior Surabaya. Jurnal Pendidikan Anak Usia Dini Hal 1-12

Sugiyono. 2016. Metode Penelitian: Kuantitatif, Kualitatif, dan $R \& D$. Bandung: Alfabeta.

Yulsyofriend. 2013. Permainan Membaca dan Menulis Anak Usia Dini. Padang: Sukabina Press.

Yuvitasari, Intan. 2015. Peningkatan Kemampuan Mengenal Kata Melalui Metode Permainan Ular Tangga Kata Pada Anak Kelompok A TK Sinar Melati Sariharjo Ngaglik Sleman Yogyakarta. Jurnal 
Pendidikan Anak Usia Dini

Edisi 2 tahun ke-4 2015 
PEDAGOGI: Jurnal Anak Usia Dini dan Pendidikan Anak Usia Dini Volume 5 Nomor 2 Agustus 2019

6P-ISSN: 2599-0438; E-ISSN: 2599-042X 